\title{
Cerebral fat emboli syndrome: do not miss the transcranial Doppler findings
}

\author{
Mohamed Saleh, Emmanuelle Juan
}

Department of Critical Care, Arras General Hospital, Arras, France

\section{Correspondence to} Dr Mohamed Saleh, bpco20032002@yahoo.fr

Accepted 10 April 2015
CrossMark

To cite: Saleh $\mathrm{M}$, Juan $\mathrm{E}$ BMJ Case Rep Published online: [please include Day Month Year] doi:10.1136/ bcr-2015-210445

\section{DESCRIPTION}

Isolated cerebral fat emboli syndrome with subtle clinical signs not fulfilling Gurd's criteria and diagnosed by MRI and CT changes have been previously described. ${ }^{1}$ We describe middle cerebral artery Doppler findings (figure 1) in a case of cerebral fat embolism following isolated femoral bone open fracture in a 29-year-old woman who developed unexplained postoperative coma with normal brain CT findings. On the second day of ICU admission, petechial purpura spots appeared in the upper trunk region (figure 2). Brain MRI was unfeasible. Middle cerebral artery Doppler showed

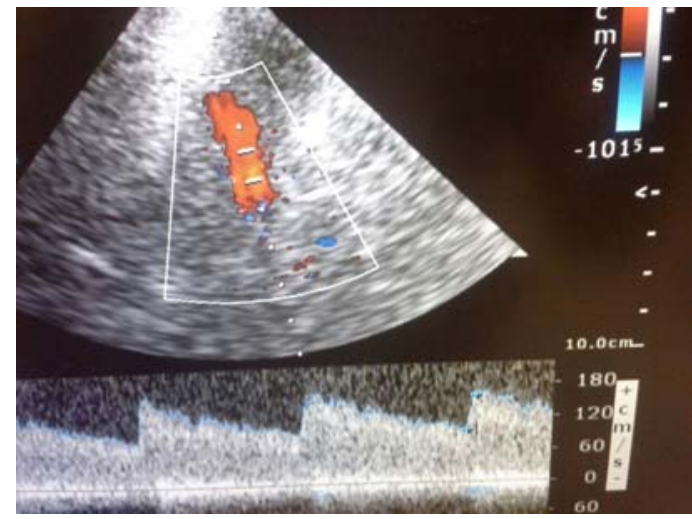

Figure 1 Upper slide: Colour Doppler showing dilated middle cerebral artery. Lower slide: Pulsed Doppler recording high mean velocity $(160 \mathrm{~cm} / \mathrm{s})$.

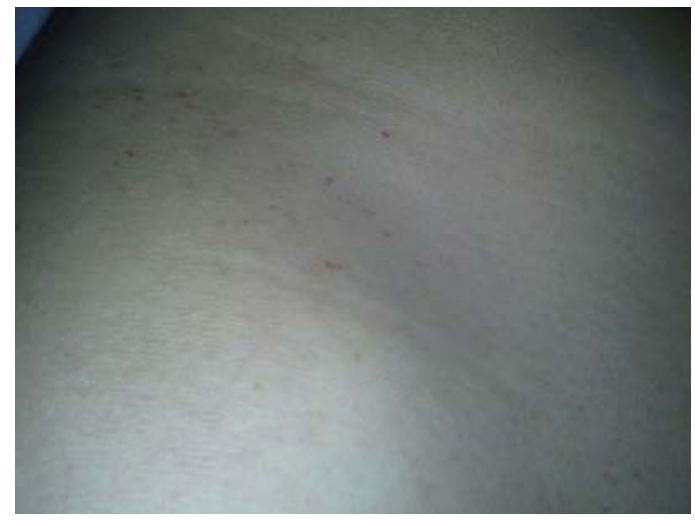

Figure 2 Tiny purpuric skin lesions in the right scapular region. a very high mean velocity value of $160 \mathrm{~cm} / \mathrm{s}$ (our reference range is set between 50 and $70 \mathrm{~cm} / \mathrm{s}$ ) in the absence of head trauma and absence of gross findings on brain CT. Colour Doppler showed a markedly dilated arterial diameter (figure 1). These findings were highly suggestive of marked hyperaemia occurring during a cerebral fat emboli syndrome and are in accordance with histological findings suggesting a direct vascular toxic effect of fat emboli by-products, notably free fatty acids. ${ }^{2}$ Our patient recovered normal consciousness and was discharged 1 week later. To the best of our knowledge, this is the first description of Doppler findings in cerebral fat emboli syndrome.

\section{Learning points}

- Middle cerebral artery Doppler might be of diagnostic aid in cerebral fat embolism if brain MRI is unfeasible or inconclusive.

- While brain CT and MRI will show fat emboli related vaso-occlusive lesions and oedema, middle cerebral artery will depict hyperaemia and vasodilatation.

- As a simple as eye fundus examination, cerebral arteries Doppler could be a part of the diagnostic algorithm of cerebral fat embolism. For this, standardisation of fat embolism-related Doppler findings seems mandatory, as middle cerebral artery Doppler is easy to perform at the bedside. Furthermore, extended studies are needed to establish fat embolism-related Doppler findings in order to implement a new aid to diagnose fat embolism and to monitor its evolution.

Competing interests None declared.

Patient consent Obtained.

Provenance and peer review Not commissioned; externally peer reviewed.

\section{REFERENCES}

1 Yeap P, Kanodia AK, Main G, et al. Role of susceptibility-weighted imaging in demonstration of cerebral fat embolism. BMJ Case Rep 2015;2015:pii: bcr2014207581.

2 Szabó G. The syndrome of fat embolism and its origin. J Clin Pathol Suppl (R Coll Pathol) 1970;4:123-31. 


\section{Images in...}

Copyright 2015 BMJ Publishing Group. All rights reserved. For permission to reuse any of this content visit http://group.bmj.com/group/rights-licensing/permissions.

BMJ Case Report Fellows may re-use this article for personal use and teaching without any further permission.

Become a Fellow of BMJ Case Reports today and you can:

- Submit as many cases as you like

- Enjoy fast sympathetic peer review and rapid publication of accepted articles

- Access all the published articles

- Re-use any of the published material for personal use and teaching without further permission

For information on Institutional Fellowships contact consortiasales@bmjgroup.com

Visit casereports.bmj.com for more articles like this and to become a Fellow 